\title{
Silica-Titania-Based Organic-Inorganic Hybrid Materials for Photovoltaic Applications
}

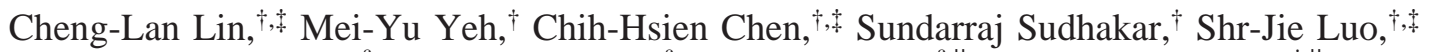 \\ Ying-Chan Hsu, ${ }^{\S}$ Chung-Yi Huang, ${ }^{\S}$ Kuo-Chuan Ho, ${ }^{\S, l}$ and Tien-Yau Luh*, ${ }^{\dagger}, \| l$ \\ Departments of Chemistry and Chemical Engineering and Institute of Polymer Science and Engineering, \\ National Taiwan University, Taipei, Taiwan 106, and Institute of Chemistry, Academia Sinica, Nangang,
} Taipei, Taiwan 115

Received February 3, 2006. Revised Manuscript Received June 25, 2006

\begin{abstract}
Silica-titania-based organic-inorganic hybrid materials (OIHMs) containing covalently bonded organic chromophores with photosensitization ability were developed. The presence of the $\mathrm{Ti}-\mathrm{O}-\mathrm{Si}$ linkage in these OIHMs was established by infrared spectroscopy. Photocurrent and photovoltage were generated upon irradiation of these OIHM films on an indium tin oxide (ITO) glass or nanocrystalline $\mathrm{TiO}_{2}$ surface. The photovoltaic properties depend on the relative molar fractions of silica and titania in the OIHM films. The OIHMs thus prepared can serve as anchoring matrixes for associating the chromophores with nanocrystalline $\mathrm{TiO}_{2}$ surfaces and can be used as active layers in photovoltaic devices. Control experiments using a blending protocol suggest that covalent bonding between the chromophores and the silicatitania hybrid networks is essential to enhancing the performance of photovoltaic devices.
\end{abstract}

\section{Introduction}

Interest in developing organic photovoltaic devices ${ }^{1-17}$ to convert solar energy into electrical energy has been steadily increasing. Various approaches are known to enhance the efficiencies of organic solar cells by improving interfacial interactions between donor and acceptor components. Organic-inorganic hybrid materials (OIHMs) containing organic moieties that are covalently bonded to the inorganic

* Corresponding author. Fax: (+886)2-2651-1488. E-mail: tyluh@ntu.edu.tw.

$\dagger$ Department of Chemistry, NTU.

Institute of Chemistry, Academia Sinica.

$\S$ Department of Chemical Engineering, NTU

"Institute of Polymer Science and Engineering, NTU.

(1) Tang, C. W. Appl. Phys. Lett. 1986, 48, 183.

(2) Grätzel, M. Nature 2001, 414, 338.

(3) Gregg, B. A. J. Phys. Chem. B 2003, 107, 4688

(4) Granström, M.; K. Petritsch, K.; Arias, A. C.; Lux, A.; Andersson, M. R.; Friend, R. H. Nature 1998, 395, 257.

(5) Peumans, P.; Uchida, S.; Forrest, S. R. Nature 2003, 425, 158.

(6) Melzer, C.; Krasnikov, V. V.; Hadziioannou, G. J. Polym. Sci. B: Polym. Phys. 2003, 41, 2665 and references therein.

(7) Sun, B.; Marx E.; Greenham, N. C. Nano Lett. 2003, 3, 961.

(8) Spanggaard, H.; Krebs, F. C. Sol. Energy Mater. Sol. Cells 2004, 83, 125.

(9) Brabec, C. J.; Sariciftci, N. S.; Hummelen, J. C. Adv. Funct. Mater. 2001, 11, 15

(10) Yu, G.; Gao, J.; Hummelen, J. C.; Wudl, F.; Heeger, A. J. Science 1995, 270, 1789 .

(11) Thompson, B. C.; Kim, Y.-G.; Reynolds, J. R. Macromolecules 2005, $38,5359$.

(12) Gebeyehu, D.; Brabec, C. J.; Sariciftci, N. S. Thin Solid Films 2002, 403-404, 271

(13) Kwon, J.-D.; Kim, P.-H.; Keum, J.-H.; Kim, J. S. Sol. Energy Mater. Sol. Cells 2004, 83, 311.

(14) Ravirajan, P.; Haque, S. A.; Durrant, J. R.; Poplavskyy, D.; Bradley, D. D. C.; Nelson, J. J. Appl. Phys. 2004, 95, 1473.

(15) Petrellaa, A.; Tamborraa, M.; Cozzolia, P. D.; Currib, M. L.; Striccolib, M.; Cosmaa, P.; Farinolaa, G. M.; Babudric, F.; Nasoc, F.; Agostiano, A. Thin Solid Films 2004, 451-452, 64.

(16) Beek, W. J. E.; Slooff, L. H.; Wienk, M. M.; Kroon, J. M.; Janssen, R. A. J. Adv. Funct. Mater. 2005, 15, 1703.

(17) Slooff, L. H.; Wienkb, M. M.; Kroona, J. M. Thin Solid Films 2004, $451-452,634$ framework are known to exhibit a range of interesting photophysical properties and applications. ${ }^{18-32} \mathrm{We}$ recently reported that efficient fluorescence resonance energy transfer (FRET) and light harvesting readily occur in silica-based OIHMs consisting of two or three covalently bonded organic chromophores. ${ }^{32}$ These observations suggest that the chromophores are in close proximity and that interchromophore interactions might take place in these OIHMs. It is envisaged that this strategy might be used to develop possible moieties for covalent anchoring to an appropriate electroactive species such that electron transfer can occur efficiently. It is known that the $\mathrm{Ti}-\mathrm{O}-\mathrm{Si}$ linkage can be obtained from the reaction of a polysiloxane with titanium alkoxide. ${ }^{33} \mathrm{We}$ expected that

(18) Gomez-Romero, P.; Sanchez, C. Functional Hybrid Materials; WileyVCH: Weinheim, Germany, 2004.

(19) Corriu, R. J. P.; Leclercq, D. Angew. Chem., Int. Ed. 1996, 35, 1420

(20) Schubert, U.; Hüsing, N.; Lorenz, A. Chem. Mater. 1995, 7, 2010.

(21) Brusatin, G.; Abbotto, A.; Beverina, L.; Pagani, G. A.; Casalboni, M.; Sarcinelli, F.; Innocenzi, P. Adv. Funct. Mater. 2004, 14, 1160

(22) Schaefer, D. W.; Beaucage, G.; Loy, D. A.; Shea, K. J.; Lin, J. S. Chem. Mater. 2004, 16, 1402.

(23) Loy, D. A.; Mather, B.; Straumanis, A. R.; Baugher, C.; Schneider, D. A.; Sanchez, A.; Shea, K. J. Chem. Mater. 2004, 16, 2041.

(24) Riehl, D.; Chaput, F.; Lévy, Y.; Boilot, J.-P.; Kajzar, F.; Chollet, P. A. Chem. Phys. Lett. 1995, 245, 36.

(25) Cheben, P.; del Monte, F.; Worsfold, D. J.; Carlsson, D. J.; Grover, C. P.; Mackenzie, J. D. Nature 2000, 408, 64.

(26) Hirai, T.; Okubo, H.; Komasawa, I. J. Mater. Chem. 2000, 10, 2592.

(27) Blair, S.; Lowe, M. P.; Mathieu, C. E.; Parker, D.; Senanayake, P. K.; Kataky, R. Inorg. Chem. 2001, 40, 5860.

(28) (a) Rottman, C.; Grader, G.; Avnir, D. Chem. Mater. 2001, 13, 3631. (b) Wright, J. D.; Higginson, N. A. C. J. Mater. Chem. 2004, 14, 201.

(29) Salin, F.; Le Saux, G.; Georges, P.; Brun, A.; Bagnall, C.; Zarzycki, J. Opt. Lett. 1989, 14, 785 .

(30) Dantas de Morais, T.; Chaput, F.; Boilot, J.-P.; Lahlil, K.; Darracq, B.; Lévy, Y. Adv. Mater. 1999, 11, 107.

(31) Pardo, R.; Zayat, M.; Levy, D. J. Mater. Chem. 2005, 15, 703.

(32) Chen, C.-H.; Liu, K.-Y.; Sudhakar, S.; Lim, T.-S.; Fann, W.-S.; Luh, T.-Y. J. Phys. Chem. B 2005, 109, 17887.

(33) Chen, W.-C.; Lee, L.-H.; Chen, B.-F.; Yen, C.-T. J. Mater. Chem. 2002, 12, 3644 . 
incorporation of organic chromophores covalently bonded to a silica-titania-based OIHM might furnish a useful entry for electron transfer and photocurrent generation. We now report an unprecedented example of using silica-titaniabased OIHMs for photovoltaic applications.

\section{Experimental Section}

General. NMR spectra were measured on a Bruker AMX 400 NMR spectrometer. FT-IR absorption spectra were obtained on a Thermo Nicolet Avatar 360 FTIR spectrometer. Surface images were recorded on a LEO 1530 field-emission scanning electron microscope (SEM). The absorption and emission spectra of the hybrid material films on ITO were measured on Hitachi U-3310 UV-visible and Hitachi F-4500 fluorescence spectrophotometers, respectively. An EG\&G PAR 273A potentiostat/galvanostat was employed for electrochemical studies. The light source was a $\mathrm{Hg}$ (Xe) arc lamp (Oriel, model 66984) equipped with an AM 1.5 global filter to simulate solar radiation.

Materials. Reagent-grade chemicals (from Acros Organics, unless otherwise specified) were employed throughout this study. Poly(ethylene glycol) was purchased from Aldrich Chemical Co. and was used as obtained. The synthesis of HT-Si was reported previously. ${ }^{32}$

1,4-Bis[4-(ethoxydimethylsilyl)styryl]-2,5-dioctyloxybenzene (TPV-Si). In a manner similar to that described previously, ${ }^{32}$ NaOEt [prepared from sodium $(1.8 \mathrm{~g}, 81 \mathrm{mmol})$ in ethanol (100 $\mathrm{mL})]$ was added to a mixture of 2,5-dioctoxy-1,4-xylylene-bis(triphenylphosphonium) dibromide (27.5 g, $27 \mathrm{mmol})$ and 4-bromobenzaldehyde $(10 \mathrm{~g}, 54 \mathrm{mmol})$ in EtOH $(150 \mathrm{~mL})$. The mixture was heated under reflux for $15 \mathrm{~h}$. After the mixture had been cooled to room temperature, methanol was added, and the resulting precipitate was collected. The solid was dissolved in toluene, and the mixture was refluxed in the presence of a trace amount of iodine for 1 day. Solvent was removed in vacuo, and the residue was washed with hexane until washings were almost colorless; the residue was then recrystallized from toluene to give the corresponding TPV $-\mathrm{Br}$ as a yellow solid $(6.16 \mathrm{~g}, 65 \%)$. mp 121-122 ${ }^{\circ} \mathrm{C}$; ${ }^{1} \mathrm{H} \mathrm{NMR}\left(400 \mathrm{MHz}, \mathrm{CDCl}_{3}\right) \delta 0.92(\mathrm{t}, J=7.0 \mathrm{~Hz}, 6 \mathrm{H}), 1.32-$ $1.43(\mathrm{~m}, 20 \mathrm{H}), 1.83-1.90(\mathrm{~m}, 4 \mathrm{H}), 4.05(\mathrm{t}, J=6.5 \mathrm{~Hz}, 4 \mathrm{H}), 7.07$ (d, $J=16.6 \mathrm{~Hz}, 2 \mathrm{H}), 7.10$ (s, 2H), 7.39 (d, $J=8.5 \mathrm{~Hz}, 4 \mathrm{H}), 7.45$ $(\mathrm{d}, J=16.6 \mathrm{~Hz}, 2 \mathrm{H}), 7.47(\mathrm{~d}, J=8.5 \mathrm{~Hz}, 4 \mathrm{H}) ;{ }^{13} \mathrm{C} \operatorname{NMR}(100$ $\left.\mathrm{MHz}, \mathrm{CDCl}_{3}\right) \delta 14.2,22.8,26.4,29.5,29.60,29.62,32.0,69.7$, 110.8, 121.2, 124.4, 126.9, 127.8, 128.1, 131.9, 137.1, 151.3.

Under Ar atmosphere, $n$-BuLi (1.2 mL, $2.5 \mathrm{M}$ in hexane, 3.0 mmol) was added dropwise to a THF (10 mL) solution of TPV$\operatorname{Br}(0.35 \mathrm{~g}, 0.5 \mathrm{mmol})$. The mixture was treated with $\mathrm{Me}_{2} \mathrm{Si}(\mathrm{OEt})_{2}$ $(0.5 \mathrm{~mL}, 3.0 \mathrm{mmol})$ at $-78^{\circ} \mathrm{C}$, warmed to room temperature, and stirred for $1 \mathrm{~h}$. EtOH $(1 \mathrm{~mL})$ was added, and the mixture was held at room temperature for an additional $30 \mathrm{~min}$. The solvent was removed in vacuo, and the residue was dissolved in toluene and then filtered. The solvent was removed in vacuo to give TPV $-\mathrm{Si}$ as a yellow solid $(0.268 \mathrm{~g}, 72 \%)$. mp $70-71{ }^{\circ} \mathrm{C} ;{ }^{1} \mathrm{H}$ NMR $(400$ $\left.\mathrm{MHz}, \mathrm{CDCl}_{3}\right) \delta 0.39(\mathrm{~s}, 12 \mathrm{H}), 0.89(\mathrm{t}, J=6.3 \mathrm{~Hz}, 6 \mathrm{H}), 1.20(\mathrm{t}, J$ $=7.0 \mathrm{~Hz}, 6 \mathrm{H}), 1.30-1.50(\mathrm{~m}, 20 \mathrm{H}), 1.80-1.89(\mathrm{~m}, 4 \mathrm{H}), 3.69(\mathrm{q}$, $J=7.0 \mathrm{~Hz}, 4 \mathrm{H}), 4.06(\mathrm{t}, J=6.7 \mathrm{~Hz}, 4 \mathrm{H}), 7.13(\mathrm{~s}, 2 \mathrm{H}), 7.14(\mathrm{~d}$, $J=16.2 \mathrm{~Hz}, 2 \mathrm{H}), 7.53(\mathrm{~d}, J=16.2 \mathrm{~Hz}, 2 \mathrm{H}), 7.54(\mathrm{~d}, J=8.1 \mathrm{~Hz}$, $4 \mathrm{H}), 7.57(\mathrm{~d}, J=8.1 \mathrm{~Hz}, 4 \mathrm{H}) ;{ }^{13} \mathrm{C} \mathrm{NMR}\left(75 \mathrm{MHz}, \mathrm{CDCl}_{3}\right) \delta-1.7$, $14.1,18.4,22.7,26.3,29.3,29.4,29.5,31.8,58.6,69.6,110.7$, 124.1, 125.9, 126.9, 128.6, 133.8, 137.1, 139.1, 151.15; MS (FAB) $\mathrm{m} / \mathrm{z}$ (rel intensity) 742 (100), 640 (35); HRMS (FAB) calcd for $\mathrm{C}_{46} \mathrm{H}_{70} \mathrm{O}_{4} \mathrm{Si}_{2}$ 742.4813, found 742.4816 .

1,4-Bis \{[3-phenyl-5-(4-(2-triethoxysilylethenyl)-phenyl)furyl]2-yl benzene $(\mathbf{P F}-\mathbf{S i})$. Under nitrogen atmosphere, a mixture of
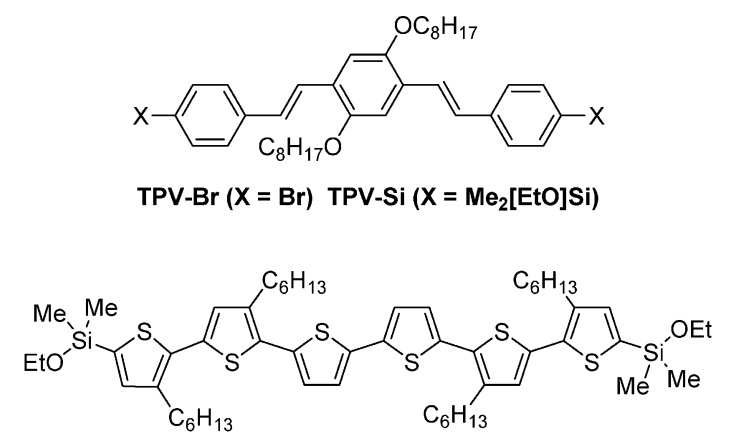

HT-Si

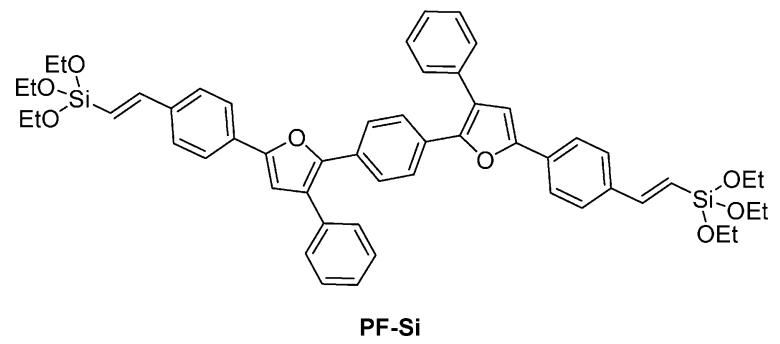

Figure 1. Structures of chromophore-containing precursors for OIHMs.

1,4-bis \{[3-phenyl-5-(4-(ethynyl)-phenyl)furyl]-2-yl\}benzene ${ }^{34,35}$ (0.13 $\mathrm{g}, 0.14 \mathrm{mmol})$, triethoxysilane $(0.07 \mathrm{~g}, 0.33 \mathrm{mmol})$, and $\mathrm{RhCl}\left(\mathrm{PPh}_{3}\right)_{3}$ (13 mg, $10 \mathrm{~mol} \%$ ) in THF (5 mL) was refluxed overnight. After removal of the solvent, the residue was taken up in $\mathrm{CH}_{2} \mathrm{Cl}_{2}$ and filtered through a short column (silica gel). The filtrate was evaporated in vacuo to give $\mathrm{PF}-\mathrm{Si} .{ }^{1} \mathrm{H}$ NMR $\left(400 \mathrm{MHz}, \mathrm{CDCl}_{3}\right)$ $\delta 1.3(\mathrm{t}, J=7 \mathrm{~Hz}, 18 \mathrm{H}), 3.9(\mathrm{q}, J=7 \mathrm{~Hz}, 12 \mathrm{H}), 6.23(\mathrm{~d}, J=19.2$ $\mathrm{Hz}, 2 \mathrm{H}), 6.84$ (s, 2H), 7.22-7.75 (m, 22H).

General Procedure for the Preparation of OIHM Films. The OIHMs were prepared using a sol-gel protocol..$^{32}$ The hybrid materials were obtained from hydrolysis and condensation reactions between the alkoxysilanes (Figure 1). In a typical run, using an OIHM with a TPV-Si/tetraisopropoxytitanium (TTIP)/tetraethoxysilane (TEOS) ratio 1:2:4 as an example, tetrabutylammonium fluoride (TBAF, 1.3 equiv) was added to a $\mathrm{CH}_{2} \mathrm{Cl}_{2}$ solution containing $0.1 \mathrm{M} \mathrm{TPV}-\mathrm{Si}$ ( 1 equiv), TEOS (2 equiv), and TTIP (4 equiv), and the mixture was kept at room temperature for 30 min. Water (13 equiv, $50 \mathrm{~mol} \%$ relative to the total number of equivalents of alkoxy moieties on silicon and titanium atoms in the reaction mixture) was then added, and the mixture was sonicated at $0{ }^{\circ} \mathrm{C}$ for $30 \mathrm{~s}$ to give a homogeneous sol solution. The sol solution transformed into a bulk gel in about $8 \mathrm{~min}$. Before the sol solution had turned into a bulk gel, it was spin-coated ( spin rate $=3000$ rpm for $20 \mathrm{~s}$ ) onto an ITO film, a quartz plate, a $\mathrm{KBr}$ disk, or a nanocrystalline $\mathrm{TiO}_{2}$-on-FTO (fluoride-doped tin oxide) electrode. Transparent yellowish films formed on the ITO or quartz plate, and a uniform coating was observed on the nanocrystalline $\mathrm{TiO}_{2}$ surface. For convenience, three OIHM films with compositions of (A) 1:2:4, (B) 1:0:2, and (C) 1:2:0 were defined.

Preparation of Nanocrystalline $\mathrm{TiO}_{2}$ Films. Nanocrystalline $\mathrm{TiO}_{2}$ films were prepared according to a literature procedure. ${ }^{36} \mathrm{TTIP}$ $(72 \mathrm{~mL}$ ) was added dropwise to a $0.1 \mathrm{M}$ nitric acid solution (430 $\mathrm{mL}$ ) under vigorous stirring. After hydrolysis, the slurry was stirred vigorously at $85-90{ }^{\circ} \mathrm{C}$ for $8 \mathrm{~h}$ to achieve peptization, and the mixture was filtered to remove nonpeptized agglomerates. The

(34) Lee, C.-F.; Yang, L.-M.; Hwu, T.-Y.; Feng, A.-H.; Tseng, J.-C.; Luh, T.-Y. J. Am. Chem. Soc. 2000, 122, 4992.

(35) Zhang, L.-Z.; Chen, C.-W.; Lee, C.-F.; Wu, C.-C.; Luh, T.-Y. Chem. Commun. 2002, 2336.

(36) Velusamy, M.; Thomas, K. R. J.; Lin, J.-T.; Hsu, Y.-C.; Ho, K.-C. Org. Lett. 2005, 7, 1899. 
sticky colloid thus obtained was heated at $240{ }^{\circ} \mathrm{C}$ for $12 \mathrm{~h}$ in an autoclave. Poly(ethylene glycol) was added $\left(30 \%\right.$ of the $\mathrm{TiO}_{2}$ weight) to prevent cracking during the course of film drying. The colloidal mixture was introduced onto one edge of the FTO glass. A glass rod was rolled over the FTO glass to homogeneously distribute the colloidal mixture containing $\mathrm{TiO}_{2}$ nanoparticles. Two parallel edges of the FTO glass were covered with $3 \mathrm{M}$ adhesive tape (ca. $100 \mu \mathrm{m}$ thick) to control the thickness of the coating. The resulting film was air-dried, then gradually heated to $450{ }^{\circ} \mathrm{C}$ at a rate of $20^{\circ} \mathrm{C} / \mathrm{min}$, and held at $450{ }^{\circ} \mathrm{C}$ for $30 \mathrm{~min}$. This procedure was repeated three times on the same FTO glass, and the thickness of the resulting layer was about $17 \mu \mathrm{m}$ as determined by SEM.

Photocurrent Measurements. The photovoltaic characteristics of the OIHM films were studied using a conventional threeelectrode system in a quartz electrochemical cell equipped with a potentiostat/galvanostat. A $\mathrm{Pt}$ wire was used as the counter electrode, and the reference electrode was $\mathrm{Ag} / \mathrm{AgCl}$. The aqueous electrolyte contained $0.1 \mathrm{M} \mathrm{KI}$, and the area of the working electrode was $1 \mathrm{~cm}^{2}$. The light had an intensity was $100 \mathrm{~mW} \mathrm{~cm}-2$ with an AM 1.5 filter, and it illuminated the OIHM-coated side of the sample.

Cyclic Voltammetric Measurements. A conventional threeelectrode electrochemical system [working electrode, Pt-disk electrode (3 mm in diameter); reference electrode, $\mathrm{Ag} / \mathrm{Ag}^{+}$(10 mM $\mathrm{AgNO}_{3}$ in $\left.\mathrm{MeCN}\right)$; counter electrode, Pt wire] equipped with a potentiostat/galvanostat was used to obtain $I-V$ curves. The substrate was dissolved in $\mathrm{CH}_{2} \mathrm{Cl}_{2}$ containing $\mathrm{Bu}_{4} \mathrm{NPF}_{6}$ as the supporting electrolyte.

Fabrication of Photovoltaic Devices. OIHM-coated nanocrystalline $\mathrm{TiO}_{2}$ films on FTO glass with an active area of $1 \mathrm{~cm}^{2}$ were used as the working electrodes for photovolatic devices. The Ptcoated (by sputtering) ITO glass was separated by a $40-\mu \mathrm{m}$-thick Surlyn 1702 (DuPont) from the working electrode. A mixture of $0.5 \mathrm{M}$ 4-tert-butyl-pyridine, $0.5 \mathrm{M} \mathrm{LiI}$, and $0.05 \mathrm{M} \mathrm{I}_{2}$ in $\mathrm{MeCN}$ and valeronitrile (volume ratio $=1: 1$ ) was used as the electrolyte to fill the gap between the electrode and the Pt-coated ITO glass by capillary force.

For comparison, a $\mathrm{TiO}_{2}$ electrode with TPV $-\mathrm{Si}$ directly anchored onto the nanocrystalline $\mathrm{TiO}_{2}$ surface through siloxane moieties was also prepared. The $\mathrm{TiO}_{2}$ electrode was immersed in an ethanolic solution of $0.3 \mathrm{mM}$ TPV-Si for $12 \mathrm{~h}$, and a photovoltaic device using this working electrode was fabricated following the same procedure as described above.

\section{Results and Discussion}

Characterization of OIHM Films. OIHM films were prepared by the treatment of TPV-Si with TTIP and TEOS at different molar ratios and were spin-coated onto quartz or ITO surfaces. The morphologies of the hybrid films on ITO were examined by SEM. In general, these transparent OIHM films exhibited homogeneous surface images (Supporting Information). OIHM films on $\mathrm{KBr}$ disks were characterized by infrared spectroscopy (Figure 2). The strong broad absorption around $1070 \mathrm{~cm}^{-1}$ was attributed to the presence of the $\mathrm{Si}-\mathrm{O}-\mathrm{Si}$ linkage in $\mathrm{B},{ }^{37,38}$ which contained no titania moiety. On the other hand, the absorption at 940 $\mathrm{cm}^{-1}$ for OIHM film A (consisting of both silica and titania moieties) suggested the presence of the $\mathrm{Ti}-\mathrm{O}-\mathrm{Si}$ moiety. ${ }^{37,38}$

Photophysical Properties of OIHM Films. The absorption and emission spectra of the OIHM films on ITO were

(37) Zeitler, V. A.; Brown, C. A. J. Phys. Chem. 1957, 61, 1174.

(38) Hu, C.; Wang, Y.; Tang, H. Appl. Catal. B: Environ. 2001, 30, 277.

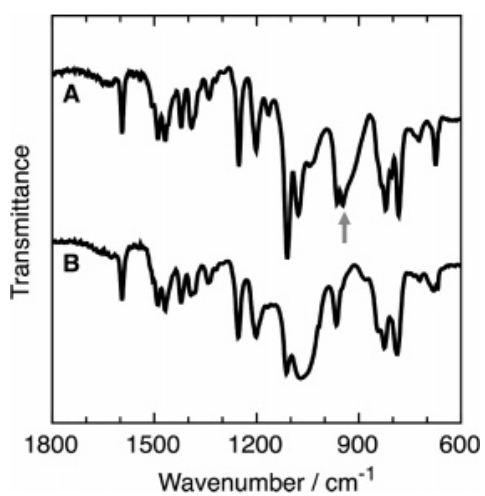

Figure 2. FTIR spectra of OIHM films A (TPV-Si/TTIP/TEOS = 1:2:4) and $\mathrm{B}(\mathrm{TPV}-\mathrm{Si} / \mathrm{TTIP} / \mathrm{TEOS}=1: 0: 2)$ on $\mathrm{KBr}$.

compared with those of $\mathrm{TPV}-\mathrm{Si}$ in $\mathrm{CHCl}_{3}$ solution (Figure 3 ). It is interesting to note that the absorption profiles of the OIHM films are slightly broader than that of the same chromophore in $\mathrm{CHCl}_{3}$. The emission peaks of the OIHM films showed red shift of about $40 \mathrm{~nm}$ relative to that of TPV-Si in $\mathrm{CHCl}_{3}$. The emission spectra of OIHM films prepared from sol solutions with different molar fractions of TTIP but with constant amount of TEOS are shown in Figure 4. The intensities of the emission profiles decreased with increasing molar fraction of titania. Presumably, electron transfer from the chromophores to the titanium oxide species occurs in these hybrid materials. These results indicate that incorporation of the titania moiety can provide an efficient electron-collection pathway such that a photocurrent can be generated.

Photocurrent Measurements. A conventional threeelectrode electrochemical system was employed to measure the photocurrent and photovoltage generated from OIHM films A-C. Figure 5 shows typical $I-V$ plots for OIHM film A upon illumination and in the dark. A photovoltage of $235 \mathrm{mV}$ was established, and an oxidative photocurrent was generated upon irradiation at AM $1.5\left(100 \mathrm{~mW} \mathrm{~cm}^{-2}\right)$. It is noteworthy that negligible current was observed when the hybrid material contained no chromophore such as TPV (Supporting Information). A film prepared from monomeric TPV-Si alone without TEOS and TTIP also generated a very small photocurrent and photovoltage $(\sim 15 \mathrm{mV}$, see the Supporting Information). These results indicate that TPVcontaining OIHM might serve as the sensitizer ${ }^{39,40}$ to convert the light energy into electric energy under these conditions. In addition, the nature of the silica-titania inorganic network in these OIHM films might also play an important role on the photovoltaic properties.

Figure 6 shows the net photocurrent responses of OIHM films $\mathrm{A}-\mathrm{C}$ on ITO upon on-off illuminations. When the inorganic framework consisted of silica alone (film B), the photocurrent was low. On the other hand, a significant increase in photocurrent was observed when titania was incorporated (A and C, Figure 6). The optimal composition was found for a TPV-Si/TTIP/TEOS ratio of 1:2:4 (OIHM film A, Supporting Information), and the photocurrent was

(39) Jaeger, A. J.; Fan, F. R. F.; Bard, A. J. J. Am. Chem. Soc. 1980, 102, 5137.

(40) Hagfeldt, A.; Grätzel, M. Chem. Rev. 1995, 95, 49. 

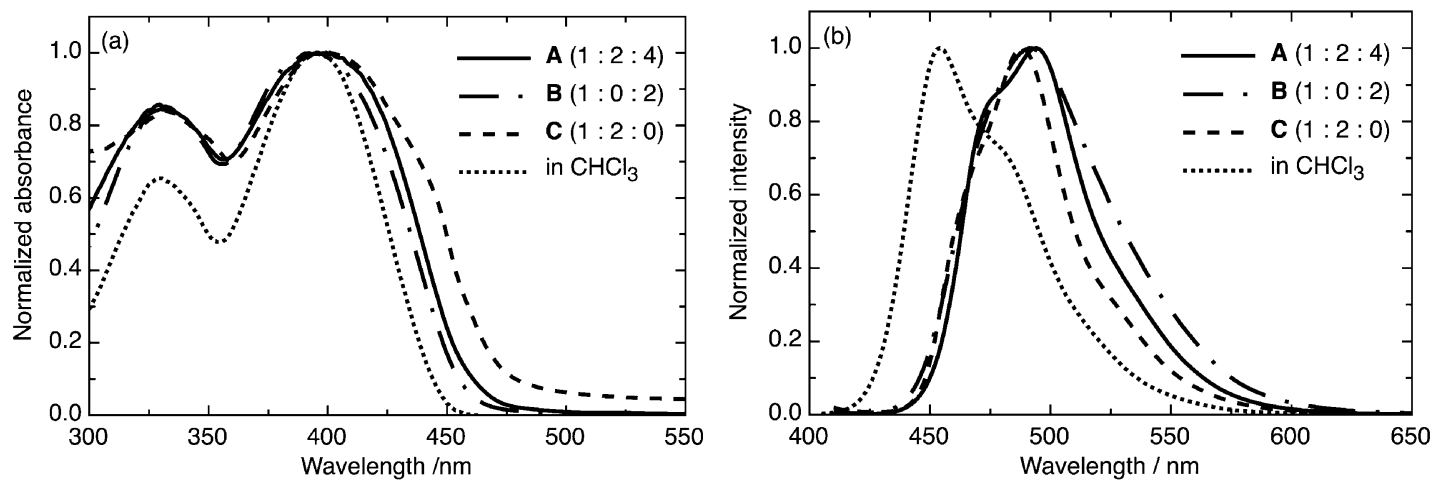

Figure 3. Normalized (a) absorption and (b) fluorescence spectra $\left(\lambda_{\text {ex }}=395 \mathrm{~nm}\right)$ of OIHM films A-C and of TPV-Si in $\mathrm{CHCl}_{3}$.

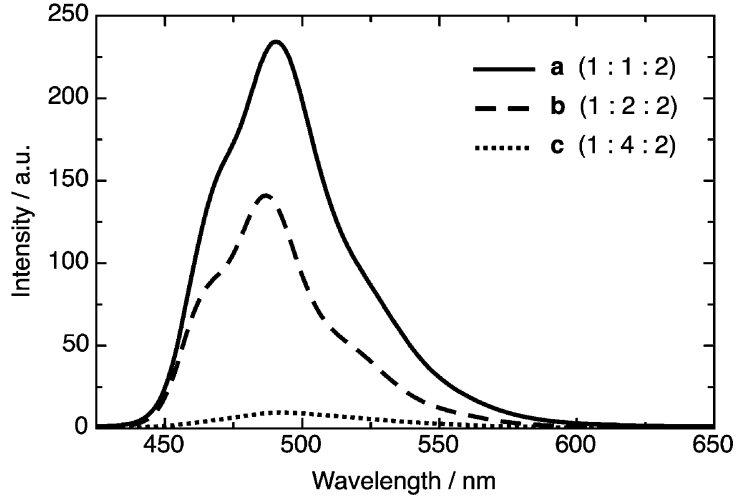

Figure 4. Titanium oxide content-dependent emission profiles $\left(\lambda_{\mathrm{ex}}=395\right.$ nm) of OIHM films with TPV-Si/TTIP/TEOS ratios of (a) 1:4:2, (b) $1: 2$ : 2 , and (c) $1: 1: 2$ on quartz.

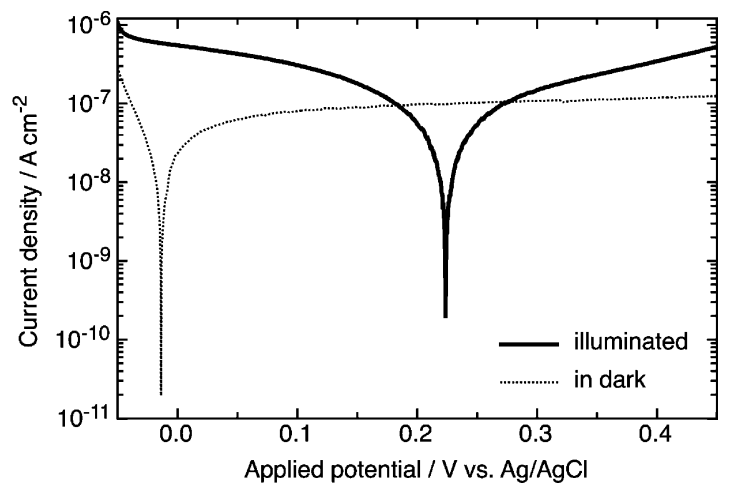

Figure 5. $I-V$ characterics of $\mathrm{A}(\mathrm{TPV}-\mathrm{Si} / \mathrm{TTIP} / \mathrm{TEOS}=1: 2: 4)$ at $\mathrm{AM}$ $1.5\left(100 \mathrm{~mW} \mathrm{~cm}^{-2}\right)$ illumination and in the dark. The scan rate was $5 \mathrm{mV}$ $\mathrm{s}^{-1}$.

enhanced about 7-fold in comparison to that of B. The efficiency decreased when a higher molar fraction of TEOS was employed (Supporting Information). As described previously, the titania species in this system can serve as a medium to accept electrons from excited chromophores. The hybrid materials might provide an interpenetrating heterojunction to mingle the donor (TPV) and acceptor (titanium oxide) moieties such that electron-transfer processes are facilitated and the photocurrent is enhanced.

Photovoltaic Devices. Judging from this strategy, it appeared that a silica-titania-based OIHM on nanocrystalline $\mathrm{TiO}_{2}$ can be used as a half-cell to convert light energy into electric energy in a photovoltaic device. Moreover, because these OIHMs contained both silica and titania moieties, covalent bonds between these hybrid materials and the $\mathrm{TiO}_{2}$ surface can be formed. Consequently, these OIHMs can

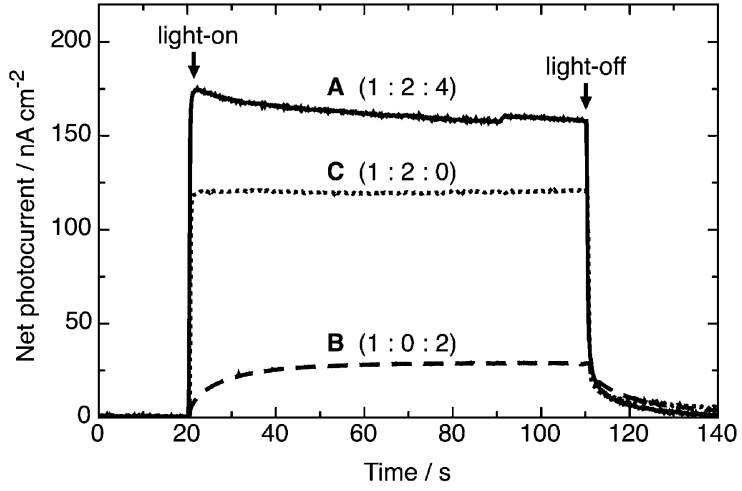

Figure 6. Net photocurrent responses of OIHM films A-C on ITO upon on-off illuminations (AM 1.5, $100 \mathrm{~mW} \mathrm{~cm}^{-2}$ ). The external bias was 100 $\mathrm{mV}$.

function as the anchoring matrixes to attach the chromophores to the $\mathrm{TiO}_{2}$ surface.

A cyclic voltammetric study of TPV-Si revealed that the oxidation occurred at $0.52 \mathrm{~V}$ vs $\mathrm{Fc} / \mathrm{Fc}^{+}$(ferrocene/ferricinium), which corresponds to a HOMO energy level of $-5.32 \mathrm{eV}$ vs vacuum. ${ }^{41,42}$ The corresponding LUMO energy level was estimated to be $-2.51 \mathrm{eV}$ on the basis of the absorption profile of TPV-Si (Figure 3). It is known that the energy of the conduction band of $\mathrm{TiO}_{2}$ is about $-4.4 \mathrm{eV}$ vs vacuum. ${ }^{2}$ These values suggested that photoinduced electron transfer from TPV-Si to $\mathrm{TiO}_{2}$ would be feasible.

OIHMs with different TPV-Si/TTIP/TEOS ratios were used to fabricate the photovoltaic devices. It is noteworthy that the concentration(s) of TEOS and/or TTIP should be kept relatively low in the preparation of the OIHM films for photovoltaic devices. In general, the TEOS concentration should be kept less than 1.0 M and that of TTIP less than $0.5 \mathrm{M}$. Otherwise, polymerization between the inorganic species is too fast to control, and the quality of the film is poor for photovoltaic studies.

An SEM image of the OIHM-coated nanocrystalline $\mathrm{TiO}_{2}$ surface is compared to that of the uncoated $\mathrm{TiO}_{2}$ surface in Figure 7. In general, a sol-gel-derived hybrid-material thin film with a thickness of several tenths of nanometers is formed when it is coated onto a substrate surface. ${ }^{18}$ The typical thickness of a $\mathrm{TiO}_{2}$ film was about $17 \mu \mathrm{m}$ as examined by SEM. The discrepancy between these two

(41) Pommerehne, J.; Vestweber, H.; Guss, W.; Mahrt, R. F.; Bässler, H.; Porsch, M.; Daub, J. Adv. Mater. 1995, 7, 551.

(42) Liu, M. S.; Jiang, X.; Liu, S.; Herguth, P.; Jen, A. K.-Y. Macromolecules 2002, 35, 3532 . 
(a)

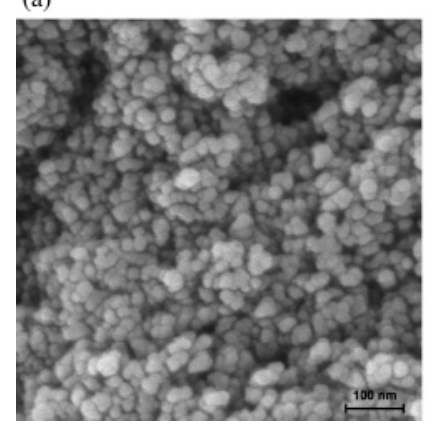

(b)

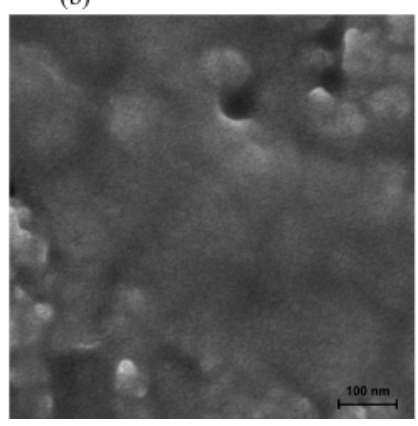

Figure 7. SEM images of nanocrystalline $\mathrm{TiO}_{2}$ electrodes: (a) bare and (b) coated with OIHM A (TPV-Si/TTIP/TEOS = 1:2:4).

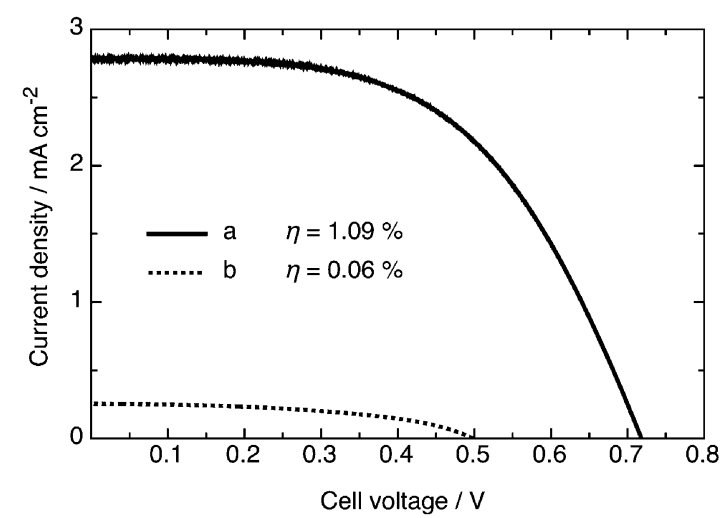

Figure 8. $I-V$ curves of the photovoltaic devices at AM $1.5(100 \mathrm{~mW}$ $\mathrm{cm}^{-2}$ ) illumination with (a) TPV-Si/TTIP/TEOS $=1: 2: 4$ and (b) TPV$\mathrm{Br} / \mathrm{TTIP} / \mathrm{TEOS}=1: 2: 4$.

Table 1. Photovoltaic Characteristics of the OIHM-Impregnated Photovoltaic Devices at AM $1.5\left(100 \mathrm{~mW} \mathrm{~cm}^{-2}\right)$ Illumination with Different TPV-Si/TTIP/TEOS Ratios

\begin{tabular}{ccccc}
\hline entry & TPV-Si/TTIP/TEOS & $\begin{array}{l}V_{\mathrm{OC}} \\
(\mathrm{V})\end{array}$ & $\begin{array}{c}J_{\mathrm{SC}} \\
\left(\mathrm{mA} \mathrm{cm}^{-2}\right)\end{array}$ & $\begin{array}{c}\eta \\
(\%)\end{array}$ \\
\hline 1 & $1: 2: 2$ & 0.70 & 1.96 & 0.71 \\
2 & $1: 2: 4$ & 0.72 & 2.79 & 1.09 \\
3 & $1: 2: 6$ & 0.71 & 2.36 & 0.88 \\
4 & $1: 2: 8$ & 0.73 & 2.08 & 0.83 \\
5 & $1: 2: 10$ & 0.72 & 1.88 & 0.75 \\
6 & $1: 1.5: 4$ & 0.70 & 2.66 & 1.01 \\
7 & $1: 2.9: 4$ & 0.74 & 1.62 & 0.80 \\
8 & $1: 4.4: 4$ & 0.70 & 0.94 & 0.39 \\
9 & $1: 2: 0$ & 0.61 & 0.81 & 0.27 \\
10 & $1: 0: 2$ & 0.58 & 0.75 & 0.26
\end{tabular}

images indicates that coating with the OIHM modified the $\mathrm{TiO}_{2}$ surface. However, SEM observations indicated no significant change in thickness between the OIHM-coated $\mathrm{TiO}_{2}$ film and the pristine surface without OIHM. Presumably, penetration of the OIHM into the porous $\mathrm{TiO}_{2}$ takes place.

The performances of the OIHM devices are summarized in Table 1. A representative $I-V$ curve of a device prepared with an OIHM having a TPV-Si/TTIP/TEOS ratio of 1:2:4 is shown in Figure 8. The highest efficiency was achieved when the OIHM was prepared with this ratio. The efficiency decreased with increasing silica molar fraction in the anchoring matrixes (entries 2-5). In a similar manner, an increase in the titania molar fraction in the anchoring matrixes also decreased the efficiency (entries 2 and 6-8).

As described in the previous section, the largest photocurrent was observed for the hybrid material with TPV-Si/ TTIP/TEOS $=1: 2: 4$, which is consistent with the results

obtained here. Again, the OIHMs made from TPV-Si with TTIP alone (entry 9) and with TEOS alone (entry 10) showed lower efficiencies in the photovoltaic devices. These results suggest that the silica-titania-based OIHMs anchoring on the $\mathrm{TiO}_{2}$ surface provide a new entry to link the chromophores onto the $\mathrm{TiO}_{2}$ electrode for photovoltaic applications. The incident photon-to-charge conversion efficiencies (IPCEs) for these devices were briefly examined. For example, the maximum IPCE generated by the device described in entry 2 of Table 1 was 34\% (Supporting Information).

In a control experiment, 1,4-bis(4-bromostyryl)-2,5-dioctyloxybenzene (TPV-Br) was blended with the silicatitania-based matrix to serve as the active layer in a photovoltaic device. The absorption profile of this blend material is similar to that of the OIHM prepared from TPV-Si. Owing to the lack of anchoring substituents, no covalent bonds could be formed from TPV $-\mathrm{Br}$ with the silica-titania moieties. As shown in Figure 8, the efficiency of the device with blended $\mathrm{TPV}-\mathrm{Br}$ was $0.06 \%$. It is apparent that the covalent bonding of the chromophores to the silica-titania hybrid framework is essential for device performance. Direct anchoring of TPV-Si onto the $\mathrm{TiO}_{2}$ surface was also examined, and the light-to-energy conversion efficiency was lower than $0.1 \%$. These results reiterate the importance of covalent bonding between the chromophores and the silica-titania-based networks. Such hybrid systems can promote charge-transfer, resulting in improvements in cell efficiency.

In a similar manner, different types of alkoxysilanes, HT$\mathrm{Si}^{32}$ and $\mathrm{PF}-\mathrm{Si}^{43}$ were used to fabricate silica-titania-based OIHMs and served as the active layer for photovoltaic devices. In preliminary tests, the efficiencies were $1.92 \%$ and $1.66 \%$ at $10 \%$ AM $\left.1.5(10 \mathrm{~mW} \mathrm{~cm})^{-2}\right)$, respectively. These results again suggest that this OIHM strategy should be a general protocol for anchoring organic dyes onto $\mathrm{TiO}_{2}$ for photovoltaic applications.

\section{Conclusions}

In conclusion, we have demonstrated the first example of sol-gel-derived OIHMs with covalently bonded chromophores for photovoltaic applications and the use of these hybrid materials as the active layers in photovoltaic devices. The alkoxysilyl substituent on the chromophore molecules provides a powerful linker that reacts with TEOS and/or TTIP to generate an interpenetration structure in the silicatitania-based network. This hybrid network can facilitate efficient electron transfer within the silica-titania-based network. In addition, because these OIHMs can be homogeneously bonded to the ITO or $\mathrm{TiO}_{2}$ surface, further electron transfer to these electroactive substrates would readily occur. The covalent bonding between the chromophores and the silica-titania hybrid networks appears to be essential in enhancing the photovoltaic properties.

The OIHM protocol developed in this study provides a new method for anchoring chromophores onto nanocrystalline $\mathrm{TiO}_{2}$ surface as the sensitizers in dye-sensitized solar

(43) Cheng, Y.-J.; Luh, T.-Y. Macromolecules 2005, 38, 4563. 
cell applications. ${ }^{2,3}$ This strategy would enable efficient interactions between chromophores and electroactive species such as $\mathrm{TiO}_{2}$, which can enhance photocurrent generation. It is known that interpenetration of donor and acceptor improves the performance of solid-state organic solar cells. ${ }^{4-17}$ The method described in this work might offer a useful tactic for the development of new types of organic solar cells. The chemistry of hybrid materials is rich, and further extensions of employing these OIHMs in organic photovoltaic devices are in progress in our laboratory.
Acknowledgment. This work was supported by the National Science Council and Academia Sinica of the Republic of China.

Supporting Information Available: SEM images of OIHMs on ITO, $I-V$ plots, net photocurrent responses of OIHM films with different TPV-Si/TTIP/TEOS ratios, and IPCE experimental procedure. This material is available free of charge via the Internet at http://pubs.acs.org.

CM0602693 